\title{
POLA DAN PERILAKU KONSUMSI RUMAH TANGGA DALAM PERSPEKTIF EKONOMI ISLAM DI KOTA MAKASSAR
}

\author{
Tuti Supatminingsih \\ Universitas Islam Negeri (UIN) Alauddin Makassar \\ Email: tutisupatminingsih@gmail.com
}

\begin{abstract}
This study discusses the pattern and behavior of household consumption in Islamic economic perspective in Makassar city. The results showed that the type of household consumption in Makassar City, dominated by expenditure for nonfood. Income, education, number of family members, number of family members, saving, credit, employment status of head of household simultaneously have a significant influence on household consumption expenditure in Makassar City. Household income, number of working family members, saving, and credit, partially have a significant effect on household consumption expenditure in Makassar City, whereas the education of head of household, the number of family member, occupation of head of household have influence which is insignificant to household consumption expenditure in Makassar City. The behavior of the family household consumption in Makassar City based on the perspective of Islamic economics, firstly, the purchase of food and non-food goods in line with the concept of needs, which is the need for more priority and has paid attention to the religious teachings of Islam; secondly, the mashlahah that is achieved with the fulfillment of food and non food needs is the acquisition of utility and blessing in consuming food and non food, thirdly, the benefits gained not only in the world but in the hereafter also, because in consumption expenditure there are still social aspects, such as zakat, infaqandsedakah, so that consumption activities that carried were based on religious values.
\end{abstract}

Keywords: pattern, behavior of household, consumption and Islamic economics

\begin{abstract}
Abstak: Penelitian ini membahas pola dan perilaku konsumsi rumah tangga dalam perspektif ekonomi Islam di kota Makassar. Hasil penelitian menunjukkan bahwa jenis konsumsi rumah tangga di Kota Makassar, didominasi oleh pengeluaran untuk nonfood. Pendapatan, pendidikan, jumlah anggota keluarga, jumlah anggota keluarga, tabungan, kredit, status pekerjaan kepala rumah tangga secara simultan memiliki pengaruh yang signifikan terhadap pengeluaran konsumsi rumah tangga. Perilaku konsumsi rumah tangga keluarga di Kota Makassar berdasarkan perspektif ekonomi Islam, pertama, pembelian barang-barang makanan dan non-makanan sesuai dengan konsep kebutuhan, yang merupakan kebutuhan untuk lebih memprioritaskan dan telah memperhatikan ajaran agama Islam; kedua, mashlahah yang dicapai dengan pemenuhan kebutuhan pangan dan bukan makanan adalah perolehan utilitas dan berkah dalam mengkonsumsi makanan dan non makanan, ketiga, manfaat yang
\end{abstract}


| Diktum: Jurnal Syari'ah dan Hukum, Volume 16, Nomor 2 Desember 2018 : 307 - 338

diperoleh tidak hanya di dunia tetapi di akhirat juga, karena dalam pengeluaran konsumsi masih ada aspek sosial, seperti zakat, infaqandsedakah, sehingga kegiatan konsumsi yang dilakukan didasarkan pada nilai-nilai agama

Katakunci : pola, perilaku rumah tangga, konsumsi, ekonomi Islam, Ekonomi Islam.

\section{PENDAHULUAN}

\subsection{Latar Belakang Masalah}

Aktivitas dalam perekonomian suatu negara, konsumsi mempunyai peran penting di dalamnya serta mempuyai pengaruh yang sangat besar terhadap stabilitas perekonomian. Semakin tinggi tingkat konsumsi, semakin tinggi tingkat perubahan kegiatan ekonomi dan perubahan dalam pendapatan nasional suatu negara. Konsumsi keluarga merupakan salah satu kegiatan ekonomi keluarga untuk memenuhi berbagai kebutuhan barang dan jasa. Dari komoditi yang dikonsumsi itulah akan mempunyai kepuasan tersendiri. Oleh karena itu, konsumsi seringkali dijadikan salah satu indikator kesejahteraan keluarga. Kesejahteraan masyarakat adalah tujuan dan cita-cita suatu negara.

Perilaku konsumsi manusia biasa bersumber pada dualitas yaitu economic rasionalism dan utilitarianism yang keduanya lebih menekankan kepentingan individu (self interest) dengan mengorbankan kepentingan pihak lain. Konsep self interest rationality, meskipun secara ekonomi terkesan baik, tetap mengandung konsekuensi terhadap perilaku konsumsi yang lebih longgar karena ukuran rasional adalah selama memenuhi self interest tersebut. Sedangkan utilitarianism yang menekankan bagaimana manfaat terbesar dapat diperoleh meski harus mengorbankan kepentingan/hak pihak lain.

Teori perilaku konsumen rasional dalam paradigma ekonomi konvensional didasari pada prinsipprinsip dasar utilitarianisme. Diprakarsai oleh Bentham yang mengatakan bahwa secara umum tidak seorangpun dapat mengetahui apa yang baik untuk kepentingan dirinya kecuali orang itu sendiri. Dengan 
| Diktum: Jurnal Syari'ah dan Hukum, Volume 16, Nomor 2 Desember 2018 : 307 - 338

demikian pembatasan terhadap kebebasan individu, baik oleh individu lain maupun oleh penguasa, adalah kejahatan dan harus ada alasan kuat untuk melakukannya. Oleh pengikutnya, John Stuart Mill dalam buku On Liberty yang terbit pada 1859, paham ini dipertajam dengan mengungkapkan konsep "freedom of action" sebagai pernyataan dari kebebasan-kebebasan dasar manusia. Menurut Mill, campur tangan negara di dalam masyarakat manapun harus diusahakan seminimum mungkin dan campur tangan yang merintangi kemajuan manusia merupakan campur tangan terhadap kebebasan-kebebasan dasar manusia, dan karena itu harus dihentikan.

Kebalikan dari hal tersebut, nilai ekonomi tertinggi dalam Islam adalah falah atau kebahagiaan umat di dunia dan di akhirat yang meliputi material, spritual, individual dan sosial. Kesejahteraan itu menurut $\mathrm{Al}$ Ghazali adalah mashlaha (kebaikan). Karena itu,falah adalah manfaat yang diperoleh dalam memenuhi kebutuhan ditambah dengan berkah (falah = manfaat + berkah). Jadi yang menjadi tujuan dari ekonomi Islam adalah tercapainya atau didapatkannya falah oleh setiap individu dalam suatu masyarakat. Ini artinya dalam suatu masyarakat seharusnya tidak ada seorangpun yang hidupnya dalam keadaan miskin.

Tujuan utama konsumsi seoarang muslim adalah sebagai sarana penolong untuk beribadah kepada Allah. Sesungguhnya mengkonsusmsi sesuatu dengan niat untuk meningkatkan stamina dalam ketaatan pengabdian kepada Allah akan menjadikan konsusmsi itu bernilai ibadah yang dengannya manusia mendapatkan pahala. Konsumsi dalam perspektif ekonomi konvensional dinilai sebagai tujuan terbesar dalam kehidupan dan segala bentuk kegiatan ekonomi. Bahkan ukuran kebahagiaan seseorang diukur dengan tingkat kemampuannya dalam mengkonsumsi. Konsep "konsumen adalah raja" menjadi arah bahwa aktifitas ekonomi khususnya produksi untuk memenuhi 
| Diktum: Jurnal Syari'ah dan Hukum, Volume 16, Nomor 2 Desember 2018 : 307 - 338

kebutuhan konsumen sesuai dengan kadar relatifitas dari keianginan konsumen, dimana Allah SWT dalam al-Qur'an Surah Muhammad/Q.S. 47 : 12 "Dan orang-orang kafir itu bersenang-senang (di dunia) dan mereka makan seperti makannya binatang" ( tg. Muhammad: 12). ${ }^{1}$

Kota Makassar sebagai kota metropolitan berdasarkan hasil Susenas 2002 - 2007 menunjukan rata-rata pengeluaran rumah tangga di Kota Makassar selama tahun 2002 - 2006 meningkat dengan cukup berarti. Pada tahun 2002 rata-rata pengeluaran rumah tangga di Kota Makassar mencapai Rp.1.068.429, kemudian meningkat menjadi Rp.1.976.959 pada tahun 2007. Di samping peningkatan rata-rata pengeluaran, indikasi meningkatnya kesejahteraan masyarakat ditunjukkan dengan terjadinya pergeseran pola konsumsi. Pengeluaran konsumsi makanan di tahun 2002 mencapai 54,83 persen menjadi 51,74 persen untuk konsumsi makanan dan 48,26 persen untuk konsumsi bukan makanan. ${ }^{2}$
Konsumsi Islam senantiasa memperhatikan halal-haram, komitmen dan konsekuen dengan kaidah-kaidah dan hukum-hukum syariat yang mengatur konsumsi agar mencapai kemanfaatan konsumsi seoptimal mungkin dan mencegah penyelewengan dari jalan kebenaran dan dampak mudharat baik bagi dirinya maupun orang lain. Adapun kaidah/prinsip dasar konsumsi islami meliputi (1) prinsip syariah (akidah, ilmu, dan amaliah); (2) prinsip kuantitas (sederhana, kesesuaian antara pengeluaran dan pemasukan, serta tabungan dan investasi); (3) prinsip prioritas (primer, tersier, dan sekunder); (4) prinsip sosial (kepentingan umat, keteladanan, dan tidak membahayakan orang lain); (5) kaidah lingkungan; dan (6) beretika islami. $^{3}$

Berdasarkan hal tersebut, penelitian ini akan fokus untuk mengkaji pola dan perilaku konsumsi rumah tangga masyarakat di Kota Makassar. Kajian ini penting untuk dilakukan karena pola dan perilaku 
| Diktum: Jurnal Syari'ah dan Hukum, Volume 16, Nomor 2 Desember 2018 : 307 - 338

konsumsi masyarakat tidak hanya terikat pada aspek dualitas yaitu economic rasionalism dan utilitarianism yang keduanya lebih menekankan kepentingan individu (self interest) dengan mengorbankan kepentingan pihak lain, melainkan juga harus terikat pada falah, yaitu manfaat yang diperoleh dalam memenuhi kebutuhan ditambah dengan berkah (falah $=$ manfaat + berkah).

\subsection{Rumusan Masalah}

Berdasarkan latar belakang yang telah diuraikan di atas, apabila di analisis secara Hukum Ekonomi Islam maka dapat dirumuskan beberapa masalah antara lain:

1.1.1 Bagaimana sistem akad pada BPJS Kesehatan Mandiri di Kota Parepare?

\subsubsection{Bagaimana mekanisme pengumpulan iuran pada BPJS Kesehatan Mandiri di Kota Parepare?}

1.1.3 Bagaimana mutu jaminan BPJS Kesehatan di Kota Parepare terhadap pelayanan kesehatan bagi peserta BPJS Kesehatan Mandiri?

II. PEMBAHASAN

A. Konstruksi Teori Terhadap Pola Konsumsi Rumah Tangga Di Kota Makassar

Perilaku konsumen merupakan suatu tindakan yang tunjukkan oleh konsumen dalam hal mencari, menukar, menggunakan, menilai, mengatur barang atau jasa yang mereka anggap akan memuaskan kebutuhan mereka. Dalam arti lain perilaku ditunjukkan, yakni bagaimana konsumen mau mengeluarkan sumber dayanya yang terbatas seperti uang, waktu, tenaga untuk mendapatkan/ menukarkan dengan barang atau jasa yang diinginkannya.

Agar memperoleh gambaran yang jelas tentang perilaku konsumen, berikut akan dikemukakan definisi perilaku konsumen menurut beberapa penulis. Hawkins ${ }^{4}$ mengemukakan bahwa perilaku konsumen (consumer behavior) adalah studi terhadap individu, kelompok atau organisasi dan proses yang mereka gunakan untuk 
| Diktum: Jurnal Syari'ah dan Hukum, Volume 16, Nomor 2 Desember 2018 : 307 - 338

memilih, mengamankan, menggunakan dan menentukan produk, service, pengalaman atau ide untuk memuaskan kebutuhan dan dampak proses tersebut pada konsumen atau masyarakat. Engel $^{5}$ menyatakan bahwa perilaku konsumen adalah tindakan yang langsung terlibat untuk mendapatkan, mengkonsumsi dan menghabiskan produk dan jasa, termasuk proses yang mendahului dan mengikuti tindakan ini. Dari berbagai definisi tersebut dapat ditarik beberapa kesimpulan bahwa (1) perilaku konsumen menyoroti perilaku baik individu maupun rumah tangga; (2) inti dari perilaku konsumen adalah proses pengambilan keputusan pembelian barang atau jasa; (3) tujuan mempelajari perilaku konsumen adalah untuk menyusun strategi pemasaran yang berhasil.

Lebih lanjut Mowen ${ }^{6}$

menyatakan bahwa, perilaku

konsumen (consumer behaviour)

didefinisikan sebagai studi tentang unit pembelian (buying units) dan proses pertukaran yang melibatkan perolehan, konsumsi dan pembuangan barang, jasa, pengalaman serta ide-ide.

Sedangkan menurut Kotler $^{7}$, perilaku konsumen merupakan studi tentang cara individu, kelompok, dan organisasi menyeleksi, membeli, menggunakan, dan memposisikan barang, jasa, gagasan, atau pengalaman untukmemuaskan kebutuhan dan niat mereka.

Schiffman dan Kanuk $^{8}$
mendefinisikan perilaku konsumen
sebagai perilaku yang diperlihatkan
konsumen dalam mencari, membeli,
menggunakan, mengevaluasi,dan
menghabiskan produk serta jasa yang
konsumen harapkan akan memuaskan
kebutuhannya. Selain itu, studi
perilaku konsumen adalah suatu studi
mengenai bagaimana seorang individu
membuat kntukan
mengalokasikan sumberdaya yang
tersedia (waktu, uang, usaha,dan
energi).
Engel, Blackwell, dan Miniard ${ }^{9}$
mengartikannya sebagai tindakan yang
langsung terlibat dalam mendapatkan,
mengkonsumsi, dan menghabiskan


| Diktum: Jurnal Syari'ah dan Hukum, Volume 16, Nomor 2 Desember 2018 : 307 - 338

produk serta jasa, termasuk proses keputusan yang mendahului dan mengikuti tindakan ini.

Perilaku konsumen merupakan semua kegiatan, tindakan, serta proses psikologis yang mendorong tindakan tersebut pada saat sebelum membeli, ketika membeli, menggunakan, menghabiskan produk dan jasa setelah melakukan hal-hal diatas atau kegiatan mengevaluasi.

Peter dan Olson ${ }^{10}$ menyatakan bahwa perilaku konsumen adalah soal keputusan. Lebih jauh lagi, keputusan adalah soal pilihan. Untuk lebih jelasnya mereka menyatakan bahwa keputusan meliputi suatu pilihan "antara dua atau lebih alternatif tindakan atau perilaku”.

Solomon ${ }^{11}$ menyatakan bahwa, "consumer behavior is the process involved when individuals or groups selest, purchase, use, and dispose of goods,services, ideas, or experiences to satisfy their needs and desires". Yang dapat diartikan bahwa perilaku konsumen merupakan suatu proses yang melibatkan seseorang ataupun suatu kelompok untuk memilih, membeli, menggunakan dan memanfaatkan barang-barang, pelayanan, ide, ataupun pengalan untuk memenuhi kebutuhan dan niat.

Demikian pula dalam konsumsi, Islam memposisikan sebagai bagian dari aktifitas ekonomi yang bertujuan mengumpulkan pahala menuju falah (kebahagiaan dunia dan akherat). Motif berkonsumsi dalam Islam pada dasarnya adalah mashlahah (public interest or general human good $)^{12}$ atas kebutuhan dan kewajiban. Sementara itu Yusuf Qardhawi $^{13}$ menyebutkan beberapa variabel moral dalam berkonsumsi, di antaranya; konsumsi atas alasan dan pada barang-barang yang baik (halal), berhemat, tidak bermewah-mewah, menjauhi hutang, menjauhi kebakhilan dan kekikiran. Dengan demikian aktifitas konsumsi merupakan salah satu aktifitas ekonomi manusia yang bertujuan untuk meningkatkan ibadah dan keimanan kepada Allah SWT dalam rangka mendapatkan kemenangan, kedamaian dan 
| Diktum: Jurnal Syari'ah dan Hukum, Volume 16, Nomor 2 Desember 2018 : 307 - 338

kesejahteraan akherat (falah), baik dengan membelanjakan uang atau pendapatannya untuk keperluan dirinya maupun untuk amal shaleh bagi sesamanya. Sedangkan pada perspektif konvensional, aktifitas konsumsi sangat erat kaitannya dengan maksimalisasi kepuasan (utility). Sir John R. Hicks ${ }^{14}$ menjelaskan tentang konsumsi dengan menggunakan parameter kepuasan melalui konsep kepuasan(utility)yangtergambar dalam kurva indifference (tingkat kepuasan yang sama). Hicks mengungkapkan bahwa individu berusaha memenuhi kebutuhan hidupnya melalui aktifitas konsumsi pada tingkat kepuasan yang maksimal menggunakan tingkat pendapatannya (income sebagai budget constraint).

Dalam Islam tahapan pemenuhan keperluan hidup boleh jadi seperti yang Maslow gambarkan, namun pemuasan keperluan hidup setelah tahapan pertama (kebutuhan dasar) akan dilakukan ketika secara kolektif yaitu kebutuhan dasar masyarkat sudah pada posisi yang aman. Ketika, masyarakat sudah terpenuhi kebutuhan dasarnya, maka tidak akan ada implikasi negatif yang muncul. Dengan demikian diperlukan peran negara dalam memastikan hal ini. Diakui ada beberapa mekanisme dalam sistem ekonomi Islam yang tidak akan berjalan efektif jika tidak ada campur tangan negara.

Parameter kepuasan dalam ekonomi Islam bukan hanya terbatas pada benda-benda konkrit (materi), tapi juga tergantung pada sesuatu yang bersifat abstrak, seperti amal shaleh yang manusia perbuat. Kepuasan dapat timbul dan dirasakan oleh seorang manusia muslim ketika harapan mendapat kredit poin dari Allah SWT melalui amal shalehnya semakin besar. Pandangan ini tersirat dari bahasan ekonomi yang dilakukan oleh Hasan Al Banna. ${ }^{15}$ Beliau mengungkapkan firman Allah yang mengatakan: "Tidakkah kamu perhatikan sesungguhnya Allah telah menundukkan untuk (kepentingan)mu apa yang di langit dan apa yang di bumi dan menyempurnakanuntukmu 
| Diktum: Jurnal Syari'ah dan Hukum, Volume 16, Nomor 2 Desember 2018 : 307 - 338

nikmat-Nya lahir dan bathin." (QS Lukman(31): 20)

Dengan demikian sangat jelas terlihat bahwa perilaku ekonomi Islam tidak didominasi oleh nilai alamiah yang dimiliki oleh setiap individu. Terdapat nilai diluar diri manusia yang kemudian membentuk perilaku ekonomi. Nilai ini diyakini sebagai tuntunan utama dalam hidup dan kehidupan manusia.

Ekonomi

Islam

menggabungkan pandangan positif dan normatif dalam prinsip-prinsipnya dan mendefinisikan konsumen sebagai pemaksimalan utilitas material serta kebutuhan dan kebutuhan spiritual, dimana, norma dan nilai religius adalah faktor yang kuat (Chapra, 1995) ${ }^{16}$. Mannan $(1984)^{17}$ dalam bukunya menyerukan kehadiran konsumen sebagai orang Islam. Selain faktor nilai netral (seperti disposable income, wealth), nilai faktor yang diisikan (seperti kepercayaan, agama) juga penting untuk menentukan keinginan dan tuntutan konsumen Islam (Kahf, $\left.1980^{18}, 1996^{19}\right)$. Hassan $\left(1985^{20}\right.$,
$2005^{21}$ ) mengkritik kerangka konsumsi Fahim khan $(1995)^{22}$ dan membahas bahwa teori konsumen Islam berhasil memodifikasi konsep kelangkaan konvensional; keinginan, kebutuhan, permintaan, utilitas, dan kepuasan, untuk memenuhi norma dan persyaratan Islam. Al-Zarqa $(1992)^{23}$ menyebutkan imbalan atau hukuman dalam hidup akhirat sebagai perbedaan utama antara konsumen Islam dan konvensional. Selain itu, konsumen Islam harus melepaskan konsumsi beberapa barang dan jasa yang berbahaya bagi masyarakat (Siddiqi, 2001) ${ }^{24}$. Oleh karena itu, model konsumen Islam memastikan keadilan sosial dan ekonomi (Haider Naqvi, 1997) ${ }^{25}$. Selain itu, khan $(2013)^{26}$ menjelaskan bahwa kerangka teori perilaku konsumen konvensional tidak cukup untuk menjelaskan semua aspek perilaku konsumen, sehingga Teori Islam paling penting disini.

Islam memandang bahwa bumi dengan segala isinya merupakan amanah Allah kepada sang khalifah agar dipergunakan sebaik-baiknya bagi 
| Diktum: Jurnal Syari'ah dan Hukum, Volume 16, Nomor 2 Desember 2018 : 307 - 338

kesejahteraan bersama. Salah satu pemanfaatan yang telah diberikan kepada khalifah adalah kegiatan ekonomi (umum) dan lebih sempit lagi kegiatan konsumsi (khusus). Islam menyarankan kepada manusia untuk memakai dasar yang benar agar mendapatkan keridhoan dari Allah Sang Pencipta. Dasar yang benar itu merupakan sumber hukum yang telah ditetapkan dan harus diikuti oleh penganut Islam.

\section{Mannan menyatakan bahwa}

sumber hukum ekonomi Islam (termasuk di dalamnya dasar hukum perilaku konsumen) ada 4 macam; Alqur'an, sunnah, ijma', qiyas dan ijtihad $^{27}$.Keempat hukum tersebut di atas menjadi sumber hukum bagi setiap tingkah laku manusia termasuk dalam kegiatan konsumsinya.

Islam adalah agama yang memiliki keunikan tersendiri dalam hal syariah. Berbeda dengan sistem lainnya, Islam mengajarkan pola konsumsi yang moderat, tidak berlebihan, tidak juga keterlaluan, lebih lanjut Al-Qur'an melarang terjadinyaperbuatantabzir dan mubazir.

\section{A. Pola dan Perilaku Konsumsi Rumah Tangga di Kota Makassar Berdasarkan Prinsip Ekonomi Islam \\ Perilaku \\ konsumsi}

merupakan salah satu aspek yang sangat menarik untuk dikaji jika dilihat dari perspektif rumah tangga keluarga. Pengeluaran rumah tangga untuk konsumsi merupakan salah satu sektor pengeluaran yang memberikan sumbangsih besar bagi pembentukan PDRB di Kota Makassar.

Secara kuantitatif, temuan penelitian ini menunjukan bahwa pendapatan rumah tangga, jumlah anggota keluarga bekerja, tabungan rumah tangga, dan kredit rumah tangga, secara parsial mempunyai pengaruh yang signifikan terhadap pengeluaran konsumsi rumah tangga di Kota Makassar, sedangkan pendidikan kepala rumah tangga, jumlah anggota keluarga, status pekerjaan kepala rumah tangga mempunyai 
| Diktum: Jurnal Syari'ah dan Hukum, Volume 16, Nomor 2 Desember 2018 : 307 - 338

pengaruh yang tidak signifikan terhadap pengeluaran konsumsi rumah tangga di Kota Makassar. Berdasarkan temuan tersebut, maka variabel yang akan dijelaskan secara kualitatif adalah variabel pendapatan rumah tangga, jumlah anggota keluarga bekerja, tabungan rumah tangga, dan kredit rumah tangga.

Berdasarkan analisis kuantitatif tersebut, terlihat bahwa pendapatan merupakan salah satu faktor yang berpengaruh signifikan terhadap konsumsi. Hasil wawancara dengan responden penelitian (R.7), menyatakan bahwa:

Tentu dalam menentukan pengeluaran konsumsi keluarga Kami, selain harga dan selera, faktor pendapatan merupakan salah satu faktor yang sangat penting. Begitulah jika hidup dalam keluarga yang pendapatannya tidak menentu. Naik turunnya konsumsi ditentukan oleh perubahan pendapatan $^{28}$.

Berdasarkan hal tersebut, terlihat bahwa, kesesuaian antara pendapatan dan konsumsi adalah hal yang sesuai dengan fitrah manusia dan realita, karena itu salah satu aksioma ekonomi menunjukan bahwa pendapatan merupakan salah satu faktor yang mempengaruhi permintaan konsumen individu, dimana permintaan menjadi bertambah jika pendapatan bertambah, dan permintaan menjadi berkurang jika pendapaan menurun, disertai tetapnya faktorfaktor yang lain.

Kesesuaian antara konsumsi dan pemasukan tersebut memiliki dalil - dalil yang jelas dalam perekonomian silam, diantaranya firman Allah dalam surah At - Talaq ayat 7: Hendaklah orang yang mampu memberi nafkah menurut kemampuannya. Dan orang yang disempitkan rezekinya hendaklah memberi nafkah dari harta yang diberikan Allah kepadanya. Allah tidak memikulkan beban kepada seseorang melainkan sekedar apa yang Allah berikan kepadanya. Allah kelak akan memberikan kelapangan sesudah kesempitan.

Berdasarkan ayat tersebut, Islam menghendaki setiap individu untuk menyesuaikan antara pendapatan dengan konsumsinya. Lebih lanjut lagi 
| Diktum: Jurnal Syari'ah dan Hukum, Volume 16, Nomor 2 Desember 2018 : 307 - 338

menurut responden penelitian (R.27), salah seorang responden yang beragama Islam dan berprofesi sebagai pelaku UMKM, menyatakan bahwa:

Saya dalam berusaha, meskipun diperhadapkan pada kondisi ekonomi yang tidak menentu, kadang-kadang tercukupi dan berlebih, kadang-kadang paspasan, namun sebagai kepala keluarga, Saya senantiasa berusaha dengan jujur dalam berdagang. Saya tidak pernah menipu pembeli dan selalu berkata jujur terhadap kondisi barang yang Saya jual. Saya takut pendapatan yang Saya peroleh dari berdagang merupakan rezeki yang tidak halal, oleh karena itu, dalam berdagang, Saya selalu jujur agar pendapatan yang Saya peroleh merupakan pendapatan yang halal untuk dikonsumsi oleh keluarga Saya ${ }^{29}$.

Berdasarkan hasil wawancara tersebut, terlihat bahwa responden yang berprofesi sebagai pedagang (pelaku UMKM), juga senantiasa mempertimbangkan aspek sumber pendapatan yang halal bagi komsumsi rumah tangganya. Jawaban singkat juga diberikan oleh R.110 yang merupakan pedagang dengan etnis tionghoa. R.110 secara singkat menyatakan bahwa:

Saya berdagang itu modalnya kejujuran. Jika Saya jujur, maka pendapatan Saya juga akan melimpah $^{30}$.

Hampir sama dengan R.27, R.110 juga menyatakan bahwa pendapatan yang diperoleh senantiasa dilakukan melalui cara-cara yang halal, agar pendapatan tersebut halal bagi komsumsi rumah tangganya. Berdasarkan hasil wawancara tersebut, dapat diketahui baik, rumah tangga muslim, maupun rumah tangga non muslim senantiasa berusaha agar pendapatan yang digunakan untuk konsumsi berasal dari sumber-sumber yang halal.

Mengingat nilai-nilai Islam merupakan faktor intern dalam rumah tangga seorang muslim, maka haruslah dipahami bahwa seluruh proses aktifitas ekonomi di dalamnya, harus dilandasi legalitas halal haram, mulai dari: produktivitas (kerja), hak kepemilikan, konsumsi (pembelanjaan), transaksi, dan investasi. Aktifitas yang terkait dengan aspek hukum tersebut kemudian 
| Diktum: Jurnal Syari'ah dan Hukum, Volume 16, Nomor 2 Desember 2018 : 307 - 338

menjadi landasan bagaimana seorang muslim melaksanakan proses distribusi pendapatannya. Islam tidak bisa menolerir distribusi pendapatan yang sumbernya diambil dari yang haram. Karena cara distribusi pendapatan dalam keluarga muslim juga akan bernuansa hukum (wajib-sunnah).

Selain berusaha agar pendapatan bersumber dari sumber yang halal, ditemukan juga fakta bahwa agar pendapatan tersebut memiliki berkah dalam pemanfaatannya, terdapat juga responden penelitian yang sebelum membelanjakan pendapatannya, senantiasa menyisihkan sebagian pendapatannya untuk sedekah, wawancara yang dilakukan dengan R.92, menyatakan bahwa:

Saya tidak pernah membuat perencanaan untuk bersedekah, tetapi setiap Saya memperoleh pendapatan, pasti ada bagian dari pendapatan Saya tersebut yang Saya sumbangkan baik dalam bentuk materi ataupun nonmateri kepada orang-orang yang membutuhkan agar harta/uang/pedapatan yang Saya peroleh ada berkahnya ${ }^{31}$.
Demikian pula yang dilakukan oleh R.57, yang menyatakan bahwa:

Saya selalu menyisihkan sebagian pendapatan yang Saya peroleh untuk Saya infaqkan di masjid setiap shalat jumat. Terkadang pula ketika bertemu dengan pengemis di jalan, Saya juga memberikan sedekah ${ }^{32}$.

Berdasarkan hal tersebut, dapat diketahui bahwa baik R.92, maupun R.57 menyisihkan sebagian pendapatannya untuk disedekahkan kepada orang-orang yang membutuhkan. Sedekah yang dilakukan tersebut terkait dengan persoalan distribusi pendapatan. Distribusi pendapatan dalam konteks rumah tangga akan sangat terkait dengan istilah shadaqah. Pengertian shadaqah disini bukan berarti sedekah dalam konteks pengertian bahasa Indonesia. Karena shadaqah konteks terminologi Al-Qur'andapatdipahami dalam dua aspek, yaitu:(1)shadaqah wajibah yang berarti bentuk-bentuk pengeluaran rumah tangga yang berkaitan dengan distribusi pendapatan berbasis kewajiban. Untuk kategori ini bisa berarti kewajiban personal 
| Diktum: Jurnal Syari'ah dan Hukum, Volume 16, Nomor 2 Desember 2018 : 307 - 338

seseorang sebagai muslim, seperti warisan dan bisa juga berarti kewajiban seorang muslim dengan muslim lainnya, seperti jiwar (bantuan yang diberikan berkaitan dengan urusan bertetangga) dan masaadah (memberikan bantuan kepada orang lain yang mengalami musibah); (2) shadaqah nafilah (sunnah) yang berarti bentuk-bentuk pengeluaran rumah tangga yang berkaitan dengan distribusi pendapatan berbasis amal kariatif, seperti sedekah.

Dari uraian diatas, dapat disimpulkan yang menjadi penekanan dalam konsep distribusi pendapatan adalah banyak hak Allah dan RasulNya serta orang atau muslim lain dari setiap pendapatan seorang muslim. Hal ini juga diarahkan sebagai bentuk dari takaful ijtima'i (jaminan sosial) seorang muslim dengan keluarga dan dengan orang lain, sehingga menjamin terjadinya minimalisasi ketidaksetaraan pendapatan (unequality income) dan keadilan sosial (social justice).

Selain faktor pendapatan, faktor lain yang berpengaruh terhadap pengeluaran konsumsi adalah jumlah anggota keluarga yang bekerja dan status pekerjaan kepala rumah tangga. Kedua faktor tersebut erat kaitannya dengan bekerja sebagai sarana ibadah dan sarana memenuhi kebutuhan keluarga.Menurut al-Kharsani, bekerja adalah sesuatu yang dikeluarkan oleh seseorang sebagai profesi, sengaja dilakukan untuk mendapatkan penghasilan. Bekerja dapat juga diartikan sebagai pengeluaran energi untuk kegiatan yang dibutuhkan oleh seseorang untuk mencapai tujuan tertentu. Bekerja adalah melakukan suatu pekerjaan (perbuatan); berbuat sesuatu $^{33}$.

Dalam perspektif Islam, bekerja tidak sekedar kegiatan yang dilakukan dalam mengumpulkan materi dengan tujuan untuk memenuhi kebutuhan hidup keluarga. Akan tetapi, bekerja merupakan implementasi dari aqidah dan juga merupakan bagian dari ibadah. Dengan demikian, dalam perspektif ekonomi Islam seorang lakilaki dewasa dan baligh ia harus gesit dalam bekerja, dan bekerja merupakan 
| Diktum: Jurnal Syari'ah dan Hukum, Volume 16, Nomor 2 Desember 2018 : 307 - 338

kewajiban kepada Allah $^{34}$.

Bekerja merupakan aktifitas yang dilakukan dalam rangka memenuhi kebutuhan hidup baik dirinya sendiri maupun orang-orang yang menjadi tanggungannya. Oleh karena itu, Islam sangat benci dan memerangi sikap malas dan memintaminta. Rasul SAW pernah bersabda: Ibnu Umar RA.Berkata, "KetikaNabi saw. Berkhotbah di atas mimbar danmenyebut sedekah dan mintaminta, beliau bersabda, "Tanganyangdiataslebihbaik daripada tangan yang di bawah, tangan yang di atas memberi dan tangan yang di bawah menerima."

Islam sangat mencela orang yang mampu untuk berusaha dan memiliki badan sehat, tetapi tidak mau berusaha, melainkan hanya menggantungkan hidupnya pada orang lain. Misalnya, dengan cara memintaminta. Keadaan seperti itu sangat tidak sesuai dengan sifat umat Islam yang mulia dan memiliki kekuatan, sebagaimana dinyatakan dalam firmanNya: Kekuatan itu bagi Allah, bagi
rasul-Nya dan bgai orang-orang yang beriman (QS. Al-Munafiqun:8)

Dengan demikian, seorang peminta-peminta, yang sebenarnya mampu mencari kasab dengan tangannya, selain telah merendahkan dirinya, ia pun secara tidak langsung telah merendahkan ajaran agamanya yang melarang perbuatan tersebut. Bahkan ia dikategorikan sebaga kufur nikmat karena tidak menggunakan tangan dan anggota badannya untuk berusaha mencari rezeki sebagaimana diperintahkan syara'. PadahalAllahpasti memberikan rezekikepada setiap makhluk-Nya yang berusaha.Allah SWT berfirman: Dan tidak ada suatu binatang melata pun di bumi melainkan Allah-lah yang memberi rezkinya, dan dia mengetahui tempat berdiam binatang itu dan tempat penyimpanannya. semuanya tertulis dalam Kitab yang nyata (Lauh mahfuzh). (QS. Hud:6)

Dalam hadits dinyatakan dengan tegas bahwa tangan orang yang di atas (pemberi sedekah) lebih baik 
| Diktum: Jurnal Syari'ah dan Hukum, Volume 16, Nomor 2 Desember 2018 : 307 - 338

daripada tangan yang di bawah (yang diberi). Dengan kata lain, derajat orang yang pemberi lebih tinggi daripada derajat peminta-minta. Maka seyogyanya bagi setiap umat Islam yang memiliki kekuatan untuk mencari rezeki, berusaha untuk bekerja apa saja yang penting halal. Hal tersebut sesuai dengan hasil wawancara yang dilakukan terhadap R.71, seorang tukang kayu yang menyatakan bahwa:

Usaha yang Saya geluti pendapatannya tidak menentu, kadang banyak, kadang sedikit. Untuk ukuran orang tua yang memiliki anak yang sedang bersekolah Saya cukup berusaha saja seperti ini, yang penting halal dan Saya tidak pernah meminta-minta kepada orang lain ${ }^{35}$.

Bagi orang yang selalu membantu orang lain, di samping akan mendapatkan pahala kelak di akherat, Allah juga akan mencukupkan rezekinya di dunia. Dengan demikian, pada hakekatnya dia telah memberikan rezekinya untuk kebahagiaan dirinya dan keluarganya, karena Allah SWT akan memberikan balasan yang berlipat dari bantuan yang ia berikan kepada orang lain.

Orang yang tidak memintaminta dan menggantungkan hidup kepada orang lain, meskipun hidupnya serba kekurangan, lebih terhormat dalam pandangan Allah SWT dan Allah akan memuliakannya akan mencukupinya. Orang Islam harus berusaha memanfaatkan karunia yang diberikan oleh Allah SWT, yang berupa kekuatan dan kemampuan dirinya untuk mencukupi hidupnya disertai doa kepada Allah SWT.

Adanya kewajiban berusaha bagi manusia, tidak berarti bahwa Allah swt. tidak berkuasa untuk mendatangkan rezeki begitu saja kepada manusia, tetapi dimaksudkan agar manusia menghargai dirinya sendiri dan usahanya, sekaligus agar tidak berlaku semena-mena atau melampaui batas, sebagaimana dinyatakan oleh Syaqiq Ibrahim $^{36}$ dalam menafsirkan ayat: Dan jikalau Allah melapangkan rezki kepada hamba-hamba-Nya tentulah mereka akan melampaui batas di muka bumi, 
| Diktum: Jurnal Syari'ah dan Hukum, Volume 16, Nomor 2 Desember 2018 : 307 - 338

tetapi Allah menurunkan apa yang dikehendaki-Nya dengan ukuran. Sesungguhnya dia Maha mengetahui (keadaan) hamba-hamba-Nya lagi Maha Melihat (QS. Asy-Syura:27).

Menurutnya, seandainya Allah SWT, memberi rezeki kepada manusia yang tidak mau berusaha, pasti manusia semakin rusak dan memiliki banyak peluang untuk berbuat kejahatan. Akan tetapi, Dia mahabijaksana dan memerintahkan manusia untuk berusaha agar manusia tidak banyak berbuat kerusakan.

Perintah bekerja telah Allah SWT wajibkan semenjak nabi yang pertama, Adam as sampai nabi yang terakhir, Muhammmad SAW. Perintah ini tetap berlaku kepada semua orang tanpa membeda-bedakan pangkat, status dan jabatan seseorang. Dari beberapa dalil al-Quran di atas terlihat jelas dan dapat dipahami bahwa bekerja merupakan bentuk ikhtiar yang harus dilakukan oleh seorang hamba (manusia), dan dengan bekerja bukanlah merupakan sebab seseorang mendapatkan rezki dari Allah SWT, karena setiap makhluk yang diciptakan sudah dijamin rezkinya oleh Allah SWT.

Faktor selanjutnya yang berpengaruh signifikan terhadap pengeluaran konsumsi adalah tabungan rumah tangga. Sebagian mengatakan bahwa menabung sebenarnya tidak dianjurkan dalam Islam, alasannya karena tabungan sejatinya umat muslim adalah tabungan di akhirat, sedangkan tabungan dunia tidak dianjurkan. Akibat adanya tabungan akhirat ini, maka pengeluaran konsumsi menjadi semakin besar. Merujuk kepada model konsumsi Fahim Khan, yang memasukkan semua pengeluaran akhirat (zakat, sedekah, infak dan wakaf dan sebagainya) ke dalam konsumsi, dengan asumsi bahwa konsumsi total terdiri atas konsumsi dunia dan konsumsi akhirat.Sehingga dengan demikian pengeluaran untuk konsumsi menjadi besar dan akibatnya tabungan menjadi kecil bahkan mendekati 0 . Temuan penelitian ini menunjukan bahwa menabung itu penting bagi rumah tangga keluarga, 
| Diktum: Jurnal Syari'ah dan Hukum, Volume 16, Nomor 2 Desember 2018 : 307 - 338

dengan catatan tabungan yang dalam hal ekonomi dan keuanganpun dilakukan bukanlah untuk menumpuk Islam memberikan solusi. Terdapat harta, melainkan untuk berjaga-jaga. banyak sekali pelajaran mengelola Hasil wawancara dengan R.32 keuangan yang bisa kita ambil dari menunjukan bahwa:

Sedapat mungkin keluarga Kami menabung. Saya takut jika ada keperluan yang mendesak, seperti ada anggota keluarga yang sakit, atau ada anggota keluarga yang harus membayar biaya pendidikan, Kami memiliki dana yang siap untuk digunakan kapan saja.

Hal tersebut menunjukan bahwa motif keluarga tersebut menabung adalah untuk berjaga-jaga. Hal tersebut mengisyaratkan kepada kita sebagai orang muslim bahwa menabung itu dianjurkan (walaupun tidak wajib) dan sangat perlu bagi kehidupan dan kesejahteraan hidup. Dalam Islam yang tidak boleh adalah menimbun atau ikhtinas. Sedangkan menabung dan menimbun adalah sesuatu yang beda ${ }^{37}$.

Islam bukan hanya bicara masalah ibadah, bukan hanya bicara masalah iman dan amal soleh. Namun Islam adalah ajaran hidup yang lengkap dan sempurna. Termasuk ajaran Islam. Dan salah satunya adalah tips menabung dari Rasulullah Muhammad SAW. Ternyata beliau sudah mengajari kita untuk menabung sejak dulu. Hal ini berdasarkan sabda beliau yang sebagaimana dikutip oleh Muhammad Shabri Majid dalam tulisannya yang berjudul Islam galak umat menabung yaitu simpanlah sebagian daripada harta kamu untuk kebaikan masa depan kamu, karena itu jauh lebih baik bagimu.Selain itu di dalam Al-quran ayat ke 47 dan 48 pada surah Yusuf juga berbicara mengenai kegiatan menabung ini sebagai berikut: Dia (Yusuf) berkata, "Agar kamu bercocok tanam tujuh tahun (berturutturut) sebagaimana biasa; kemudian apa yang kamu tuai hendaklah kamu biarkan di tangkainya kecuali sedikit untuk kamu makan.

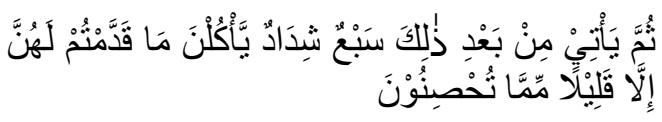

Artinya: 
| Diktum: Jurnal Syari'ah dan Hukum, Volume 16, Nomor 2 Desember 2018 : 307 - 338

Kemudian setelah itu akan datang tujuh (tahun) yang sangat sulit, yang menghabiskan apa yang kamu simpan untuk menghadapinya (tahun-tahun sulit), kecuali sedikit apa (bibit gandum) yang kamu simpan.

Maksud ayat di atas adalah berapapun hasil dari tanaman pada tujuh tahun yang subur itu maka simpanlah dalam bulir-bulirnya agar lebih awet dan tidak mudah rusak kecuali sekedar yang diperlukan untuk makan, dan makan itupun harus hemat, sedikit-sedikit saja, jangan berlebihan agar dapat untuk memenuhi kebutuhan selama tujuh tahun masa paceklik yang akan datang.

Dari ayat di atas ternyata menabung sejak dulu sudah dianjurkan sebagai simpanan untuk masa depan atau untuk menghadapi ketika masa sulit. Memang sudah menjadi hukum alam bahwa roda perekonomian terus berputar seperti roda pedati. Terkadang kita berada di atas, namun roda yang terus berputar bisa menempatkan kita pada posisi yang paling bawah. Dan kalau lebih cermat lagi, ternyata ada pelajaran berharga yang bisa kita petik dari hadits ini yaitu rumus menabung ala Rasulullah saw, dimana dijelaskan bahwa orang yang mendapatkan rahmat Allah adalah orang yang bisa menyisihkan kelebihan, yaitu orang yang berusaha dengan usaha yang baik dan membelanjakan uang secara sederhana. Ada dua syarat untuk bisa menabung, yaitu sumber penghasilan dari usaha yang baik, dan mengelola pengeluaran dengan sederhana yang bisa disimpulkan sebagai: menabung = usaha yang baik + pengeluaran yang sederhana.

Menabung adalah solusi dari Islam tentang gaya hidup yang seharusnya bagi seorang muslim diantara boros, mewah dan kikir. Daya tahan serta kekuatan ekonomi sebuah keluargapun akan sangat ditentukan oleh seberapa besar keluarga itu mampu melakukan saving. Konsumsi seseorang atau keluarga seyogyanya tidak melampaui batas maksimum dari pendapatannya. Dengan pekerjaan yang dimilikinya, seseorang sebenarnya bisa mengukur kapasitas 
| Diktum: Jurnal Syari'ah dan Hukum, Volume 16, Nomor 2 Desember 2018 : 307 - 338

maksimum pendapatannya, termasuk apabila melakukan kerja lembur. Dengan tidak melampaui batas maksimum pendapatan, diharapkan seseorang atau keluarga masih mampu menyisihkan sebagian pendapatan untuk ditabung sebagai cadangan. Hal ini sangat perlu untuk diperhatikan, mengingat fungsi cadangan sebagai saving capital, tidak saja bisa dipergunakan sebagai modal usaha, melainkan akan berpengaruh besar pula terhadap rasa aman yang secara psikis akan berpengaruh pula terhadap eksistensi seseorang. Hal tersebut sesuai dengan hasil wawancara dengan R.13 yang menyatakan bahwa:

Di keluarga Kami, sejak dini telah dibiasakan menabung. Bagi anak yang masih kecil menabungnya di celengan dan bagi anak yang sudah besar telah memiliki rekening tabungan masing-masing. Sebagai orang tua, setiap anak kami haruskan untuk menabung untuk berjaga-jaga, jika ada keperluan sekolah yang mendadak dan untuk menghindari perilaku boros ${ }^{38}$.

Dengan pernyataan ini jelaslah bahwa kegiatan menabung merupakan kegiatan yang mendukung utilitas seseorang ketika melakukan kegiatan konsumsi walaupun menabung tidak secara langsung memberi tambahan nilai guna atas barang yang dikonsumsi oleh konsumen tersebut, namun utilitas itu muncul pada rasa aman dan kepuasan konsumen ketika ia mampu menyisihkan sebagian pendapatannya pada masa sekarang untuk masa depan.

Faktor lainnya yang berpengaruh terhadap pengeluaran konsumsi adalah kredit rumah tangga. Kredit rumah tangga erat kaitannya dengan persoalan hutang piutang. Menurut ahli fikih hutang piutang adalah transaksi antara dua pihak, yang satu menyerahkan uangnya kepada yang lain secara sukarela untuk dikembalikan lagi kepadanya oleh pihak kedua dengan hal yang serupa.

Adapun yang dimaksud dengan hutang piutang adalah memberikan sesuatu kepada seseorang dengan perjanjian dia akan membayar yang sama dengan yang dipinjamnya tersebut. Yang dimaksud dengan kata "sesuatu" 
| Diktum: Jurnal Syari'ah dan Hukum, Volume 16, Nomor 2 Desember 2018 : 307 - 338

daridefinisidiatasmempunyaimaknayan gluas, selain dapat berbentuk uang juga bisa dalam bentuk barang. Asalkan barang tersebut habis karena pemakaian.

Temuan penelitian ini menunjukan bahwa pinjaman kredit yang dilakukan oleh rumah tangga keluarga, bukanlah merupakan pinjaman kredit yang sifatnya konsumtif, akan tetapi merupakan pinjaman kredit yang sifatnya investasi. Hasil wawancara dengan R.85 menunjukan bahwa:

Saya mengambil kredit dari BNI Syariah. Tujuannya adalah untuk membiayai anak Saya akan segera kuliah di Fakultas Ekonomi dan Bisnis Universitas Hasanuddin. Saya mengambil kredit juga sesuai dengan yang dibutuhkan, yaitu untuk pembayaran UKT (Uang Kuliah Tunggal) ${ }^{39}$.

Hasil wawancara tersebut menunjukan bahwa pinjaman kredit rumah tangga yang dilakukan bertujuan untuk membiayai pendidikan. Mayoritas ahli fiqh berpendapat apa yang sah untuk dijual belikan, maka sah pula untuk diutangkan, baik barang yang dapat ditakar atau ditimbang atau uang. Sedang golongan hanafi berpendapat yang boleh untuk diutangkan adalah barang yang dapat ditakar atau ditimbang, karena barang lain tidak bisa dilaksanakan dengan barangbarang tersebut, misalnya mutiara, berlian dan lain sebagainya.

\section{B. Perilaku Konsumsi Keluarga dalam Perspektif Ekonomi Islam Perilaku konsumsi menurut} ekonomi Islam adalah seorang konsumen muslim akan mempertimbangkan manfaat dan berkah yang dihasilkan dari kegiatan konsumsinya ${ }^{40}$.Perilaku konsumsi keluarga sebagai kelompok primer yang interaksinya sangat intensif dan ada dukungan emosional yang kuat secara sosiologis mempunyai fungsi dan peran yang sangat penting. Masing-masing anggota dapat berbuat hal yang berbeda untuk membeli sesuatu. Setiap anggota keluarga memiliki selera dan keinginan yang berbeda, sehingga temuan penelitian ini menunjukan bahwa mayoritas 
| Diktum: Jurnal Syari'ah dan Hukum, Volume 16, Nomor 2 Desember 2018 : 307 - 338

keluarga, selain ditentukan oleh faktor harga, penentuan konsumsinya ditentukan oleh selera dari masingmasing anggota keluarga ${ }^{41}$. Anak-anak misalnya, tidak selalu menerima apa saja dari orang tua, tetapi menginginkan juga sesuatu yang lain. Apalagi anak-anak yang sudah besar, keinginan semakin banyak. Namun demikian terdapat kebutuhan keluarga yang digunakan oleh seluruh anggota. Suatu saat anggota keluarga dapat berfungsi sebagai pengambil keputusan, tetapi pada saat yang berlainan juga dapat berbuat sebagai pembelinya. Sering dijumpai bahwa keputusan membeli dibuat bersamasama antara suami dan istri, kadangkadang anak juga termasuk, terutama untuk membeli kebutuhan seluruh keluarga.

Hasil pengkategorian NVivo (2017) menunjukan bahwa:

Setiap anggota keluarga memiliki faktor penentu yang berbeda dalam memutuskan pembelian terhadap suatu barang, namun meskipun berbeda, terdapat kesamaan antara keluarga yang satu dengan keluarga yang lainnya, yaitu keputusan pembeliannya ditentukan oleh harga dan selera.

Temuan tersebut menunjukan bahwa aspek harga dan selera sangat menentukan dalam keputusan rumah tangga dalam membelanjakan pendapatannya.Perilaku konsumsi keluarga harus memperhatikan norma dasar yang menjadi landasan dalam perilaku konsumsi muslim, yaitu:

1) Membelanjakan harta dalam kebaikan dan menjauhi sifat kikir Manusia diharuskan menggunakan harta untuk kemaslahatan manusia sendiri ataupun orang sekitar sebagai sarana beribdah kepada Allah. Membelanjakan harta sasarannya pemanfaatan harta untuk Fi Sabilillah dan pemanfaatan harta untuk diri sendiri serta keluarga. Membelanjakan harta tidak boleh melampaui batas, agar tercukupnya kebutuhan keluarga dan tidak mengemis pada keluarga yang lain. Seorang tidak boleh mengharamkan hartanya untuk keluarganya sendiri karena adanya dorongan sikap pelit dan bakhil. Tidak dibenarkan sengaja meyengsarakan keluarga dengan 
| Diktum: Jurnal Syari'ah dan Hukum, Volume 16, Nomor 2 Desember 2018 : 307 - 338

berdalih untuk beribadah atau menghemat uang. Menyengsarakan keluarga termasuk sikap tercela. Manusia dianjurkan mensyukuri nikmat Allah dengan memanfaatkan sebagaimana tujuan penciptaannya.

Perwujudan pada rumah tangga

keluarga di Kota Makassar ada sebagian yang sudah membelanjakan harta sebaik-baiknya dan membelanjakan harta untuk diri sendiri dan keluarga. Hasil pengkategorian NVivo (2017) menunjukan bahwa:

Beberapa keluargayang masuk dalam kategori keluarga menengah atas sudah menerapkan membelanjakan harta untuk diri sendiri dan keluarga dalam hal kebaikan. Ketika adanya kebutuhan dan keinginan salah satu anggota keluarga maka beliau tidak melarang untuk membelanjakan asalkan masih taraf wajar.Seperti halnya ketika si anak membutuhkan alat bantu berupa tablet dan modem untuk belajar maka beliau memenuhinya. Sedangkan untuk keluarga menengah ke bawah dalam membelanjakan harta pun demikian. Mereka memenuhi kebutuhan anakanaknya dengan baik. Ketika si anak membutuhkan biaya sekolah atau ingin melanjutkan beliaupun memilihkan sekolah yang berkualitas. Untuk keluarga wiraswasta, guru swasta dan PNS pun melakukan hal yang sama. Bahkan untuk memenuhi kebutuhan anggota keluarga tersebut kepala keluarga rela merantau, jauh dari keluarga demi keluarga yang dirumah.

Hasil pengkategorian NVivo (2017) lainnya menunjukan bahwa: Membelanjakan harta untuk diri dan keluarga 23 narasumber keluarga sudah sesuai dalam norma dasar sebagai landasan perilaku konsumsi dalam Islam. Untuk kategori membantu orang sekitarpun telah dilakukan semampu keluarga tersebut melakukan. Seperti halnya 23 keluarga membantu sanak keluarga ataupun tetangga. Keluarga melakukan tindakan bersedekah sesuai kemampuan keluarga. Ketika adanya rizki tambahan tidak lupa memberikan kepada saudara atau tetangga yang kurang mampu. Ketika dua keluarga mempunyai hajatan tidak lupa mengundang para tetangga atau saudara untuk menikmati hidangan yang ada.

Berdasarkan hasil wawancara tersebut juga dapat dipahami bahwa perilaku konsumsi muslim dari segi tujuan tidak hanya mencapai kepuasan dari konsumsi barang, melainkan 
| Diktum: Jurnal Syari'ah dan Hukum, Volume 16, Nomor 2 Desember 2018 : 307 - 338

fungsiibadahdalam rangkamendapat ridha Allah SWT.Hal ini sesuai dengan firman Allah dalam surat al an'amayat162: atakanlah: Sesungguhnya sembahyangku, ibadatku, hidupku dan matiku hanyalah untuk Allah, Tuhan semesta alam.

\section{Pencarian rezeki dan} pengeluaran harus diperhatikan. Ketika keluarga menginginkan keberkahan, maka harus memulai untuk meraih keberkahan tersebut sebelum konsumsi dilakukan. Ia harus bekerja dengan cara yang baik, karena islam mempertimbangkan proses pencarian rezeki harus dilalui dengan proses halal. Cara pembelanjaanya untuk barang atau jasa harus dengan cara baik pula

Perwujudan pengeluaran wajib dan tidak wajib dalam rumah tangga keluarga di Kota Makassar dilakukan dengan baik seperti adanya kepala keluarga yang menjadi tumpuan hidup anggota keluarga dalam menafkahi kehidupan sehari-hari. Mereka rela jauh dari sanak keluarga demi mencukupi hidup keluarganya. Untuk hal ini dilakukan dengan bertanggung jawab masing-masing keluarga. Untuk pengeluaran tidak wajib, sebagian keluarga ada yang melakukan menabung, bahkan mengajarkan anak menabung ${ }^{42}$.

\section{2) Tidak Melakukan Kemubaziran}

Seorang muslim selalu dianjurkan agar tidak berlebihan dalam membelanjakan harta dan mengarahkan berbelanjaan untuk kebutuhan yang bermanfaat, karena harta manusia akan dipertanggung jawabkan dihadapan Allah. Islam mewajibkan setiap orang membelanjakan harta miliknya untuk memenuhi kebutuhan diri pribadi dan keluarga serta menafkahkan di jalan Allah.

Perwujudan keluarga dalam hal tidak melakukan kemubaziran adalah ada yang mengontrol keinginan keluarga dengan baik dan memikirkan manfaat barang yang akan digunakan.Ada pula yang tidak memikirkan manfaat, bahkan untuk memilih barang tersebut tak peduli berapa harga yang harus dibayarkan. 
| Diktum: Jurnal Syari'ah dan Hukum, Volume 16, Nomor 2 Desember 2018 : 307 - 338

Keluarganya mampu membeli ataupun tidak.Muslim dianjurkan menyeimbangkan pendapatan dan pengeluaran.Seperti halnya ketika si anak membutuhkan sebuah modem untuk sekolah. Karena hal tersebut memang diperlukan jadi R.22 memperbolehkannya ${ }^{43}$. Lain halnya dengan R.43 ketika si anak menginginkan handphone model terbaru, beliau tanpa pikir panjang untuk membelikannya ${ }^{44}$. Ketika si anak mengambil jenjang pendidikan perguruan tinggi swasta yang cukup mahal untuk kategori keluarga Ibu R.11 ${ }^{45}$, sehingga biaya pendidikan tersebut menghutang ke saudaranya dan juga pemenuhan kebutuhan terkadang masih mengikuti gaya tetangganya. Belum bisa meminimalkan pengeluaran.Ketika beliau menginginkan pakaian, beliau mengikuti apa yang dibeli tetangganya.

Tidak melakukan kemubaziran dalam 23 rumah tangga keluarga di Kota Makassar belum sepenuhnya dilakukan sesuai norma landasan perilaku konsumsi dalam Islam.
Temuan penelitian ini menunjukan (Hasil kategorisasi Nvivo, 2017):

Untuk keluarga R.35 sudah melakukannya sesuai yang beliau tau, seperti tidak boleh melakukan pemborosan ${ }^{46}$. Untuk keluarga R.17 belum bisa demikian, karena keinginan anak masih sering dituruti $^{47}$. Untuk keluarga R.24 dalam tindakan kemubaziran kadang melakukan penghematan dan terkadang mengikuti tetangganya ${ }^{48}$. Lain halnya dengan keluarga R.24 dan R.29 yang sudah menerapkan kepentingan jangka panjang lebih penting dari pada sekarang ${ }^{49}$. Beliau sudah mengontrol keinginan keluarga. Keluarga R.19 dalam hal melakukan kemubaziran antara kebutuhan dan keinginan mereka berusaha menyeimbangkan keduanya, namun untuk R.16 ketika kebutuhan mendesak beliau mengandalkan hutang ke saudara $^{50}$.

Namun, berdasarkan hasil kategorisasi Nvivo (2017), menunjukan bahwa mayoritas rumah tangga keluarga tidak melakukan kemubaziran. Hasil temuan lainnya menunjukan bahwa:

Keluarga PNS dalam penelitian ini ada yang memperhitungkan 
| Diktum: Jurnal Syari'ah dan Hukum, Volume 16, Nomor 2 Desember 2018 : 307 - 338

pengeluaran keluarga dan ada yang hidup boros. Keluarga R.19, R.41 dan R.56 memperhitungkan pengeluaran yang ada. Seperti kebutuhan perlengkapan rumah, beliau memperdulikan manfaat barang yang akan di beli. Terutama kebutuhan akan anak-anak mereka.Kebutuhan anak-anak membeli buku juga diprioritaskan.Pendapatan keluarga cukup untuk memenuhi kebutuhan seharihari, dan masih bisa menyisihkan uang untuk ditabung. Ketika adanya kebutuhan yang mendesak tentu tidak akan merepotkan keluarga yang lain ${ }^{51}$.

Perwujudan tersebut sudah termasuk tidak melakukan kemubaziran harta. Menyeimbangkan antara kebutuhan dan keinginan keluarga. keluarga tersebut ada yang memikirkan manfaat barang yang akan dibeli. Namun masih ada keluarga yang bersikap mubazir tanpa memperdulikan manfaaat barang yang akan di beli. Salah satunya keluarga bapak abdul yang mengikuti kemauan anak. Seringnya mengikuti kemauan anak untuk membeli motor baru. Dalam Islam hal demikian tidak diperbolehkan. Ketika barang tersebut sudah memiliki maka di wajibkan memanfaatkan barang yang ada. Dalam Islam bersikap boros termasuk perbuatan yang tercela.

\section{3) Kesederhanaan}

Sikap hidup yang sederhana sangat dianjurkan oleh Islam bahkan dalam kondisi ekonomi untuk menjaga kemaslahatan masyarakat. Kesederhanan dalam pemenuhan kebutuhan bukan memenuhi kepuasan/keinginan adalah tujuan aktivitas ekonomi Islam.Perwujudannya ada beberapa keluarga yang mengontrol keinginan, mengesampingkan keinginan, mengajarkan anak untuk hidup sederhana namun tidak kekurangan. Artinya mengajarkan hidup cukup dengan kesederhanaan.

Temuan penelitian ini menunjukan bahwa (Hasil kategorisasi Nvivo, 2017):

Ada keluarga yang memenuhi kebutuhan/keinginan dengan gaya hidup boros. Seperti halnya membelikan sepeda motor anak sering mengikuti model terbaru. Ketika adanya kebutuhan mendadadak lebih mengandalakan pinjaman dari kerabat. Hidup sehari-haripun lebih memanjakan anaknya. Keluarga R.14 merasa telah mencukupi kebutuhan anakanak dengan maksimal. Artinya 
| Diktum: Jurnal Syari'ah dan Hukum, Volume 16, Nomor 2 Desember 2018 : 307 - 338

ketika ada keinginan maka tanpa pikir panjang untuk membelinya. Alasannya anakanak sudah pada dewasa, sudah mampu mencukupi hidupnya sendiri, tentunya tidak terlalu merepotkan beliau. Maka dari itu keluarga-keluarga belum mampu menyeimbangkan kesederhaan dalam perilaku konsumsinya.

Apabila dianalisis dari teori mashlahah kepuasan bukan didasarkan atas banyaknya barang yang dikonsumsi tetapi didasarkan atas baik buruknya sesuatu terhadap dirinya dan keluarganya. Kalau masih mengandalkan kerabat berarti hal yang dilakukan belum sesuai kaidah perilaku konsumsi dalam islam. Apabila mengonsumsi mengandung mudarat maka menghindari kemudaratan harus diutamakan, karena akibat dari kemudratan yang ditimbulkan mempunyai peran yang lebih besar dari pada mengambil sedikit manfaat.Terpenuhinya suatu kebutuhan juga akan memberikan kepuasan terutama jika kebutuhan tersebut disadari dan diinginkan.

\section{PENUTUP}

Pola konsumsi rumah tangga keluarga di Kota Makassar, didominasi oleh pengeluaran untuk non makanan. Hal tersebut menunjukan bahwa pengeluaran non makanan lebih besar bila dibandingkan dengan pengeluaran makanan. Pendapatan rumah tangga, pendidikan kepala rumah tangga, jumlah anggota keluarga, jumlah anggota keluarga bekerja, tabungan rumah tangga, kredit rumah tangga, status pekerjaan kepala rumah tangga secara simultan mempunyai pengaruh yang signifikan terhadap pengeluaran konsumsi rumah tangga di Kota Makassar.

Perilaku konsumsi rumah tangga keluarga di Kota Makassar ditinjau dari teori konsumsi Islam adalah, pertama, pembelian barang pangan maupun non pangan dilakukan sesuai dengan konsep kebutuhan, yaitu kebutuhan untuk yang lebih prioritas dan telah memperhatikan ajaran agama Ismlam; kedua, mashlahah yang tercapai dengan pemenuhan kebutuhan 
| Diktum: Jurnal Syari'ah dan Hukum, Volume 16, Nomor 2 Desember 2018 : 307 - 338

pangan dan non panganadalah diperolehnya utility dan keberkahan dalam mengkonsumsi barang pangan dan non pangan;ketiga, manfaat yang didapat tidak hanya di dunia saja tetapi di akhirat juga, karena di dalam pengeluaran konsumsi masih terdapat aspek sosial, seperti zakat, infak dan sedakah, sehingga kegiatan konsumsi yang dilakukan memiliki nilai-nilai keagamaan. 
| Diktum: Jurnal Syari'ah dan Hukum, Volume 16, Nomor 2 Desember 2018 : 307 - 338

\section{DAFTAR PUSTAKA}

\section{Bibliography}

Abdulahanaa. 2014. Kaidah-kaidah Keabsahan Multi Akad (Hybrid Contract). Yogyakarta: TrustMedia.

Ali, Zainuddin. 2011. Metode Penelitian Hukum. Jakarta: Sinar Grafika.

Antonio, Muhammad Syafi'i. 2001. Bank Syariah dari Teori ke Praktik. Jakarta: Gema Insani Press.

Arifin,Johar. 2016. Substansi Akad Dalam Transaksi Syariah, Al Amwal http://www.syekhnurjati.ac.id/j urnal/index.php/amwal/article/v iew/256 (diakses 28 Februari 2018)

Audit dan Modernisasi BPJS Kesehatan. 2016. Majalah Parlemantaria, Edisi EDISI $135 \mathrm{TH}$. XLVI. Jakarta: Parlementaria. http://m135-2016.pdf (diakses 7 Juni 2018).

Basrowi dan Suwandi. 2008. Memahami Penelitian Kualitatif. Jakarta: Rineka Cipta.

BPJS Kesehatan. 2014. "Peraturan Badan Penyelenggara Jaminan Sosial Kesehatan Nomor 1 Tahun $2014 \quad$ Tentang Penyelenggaraan Jaminan Kesehatan". http://Peraturan BPJS No 1 Tahun 2014_326_1.pdf (diakses 30 Mei 2018).
Bungin, Burhan. 2012. Analisis Data Penelitian Kualitatif. Jakarta: PT RajaGrafindo Persada.

Damin,Sudarman. 2012. Menjadi Peneliti Kualitatif: Ancangan Metodologi, Presentasi, dan Publikasi Hasil Penelitian untuk Mahasiswa dan Peneliti Pemula Bidang Ilmu-ilmu Sosial, Pendidikan, dan Humaniora. Bandung: CV Pustaka Setia.

Departemen Agama RI. 1998. Alqur'an dan Terjemahnya dengan Transliterasi Arab. Semarang: PT. Karya Toha Putra Semarang.

Djazuli, A. 2006. Kaidah-Kaidah Fikih : Kaidah-Kaidah Hukum Islam dalam Menyelesaikan MasalahMasalah Praktis. Jakarta: Kencana Media Group.

Fauzia, Ika Yunia dan Abdul Kadir Riyadi. 2014. Prinsip Dasar Ekonomi Islam Persfektif Maqasid al-Syari'ah. Jakarta: Kencana.

Ikhsan, Muhammad. 2016. "Bab II Landasan Teori Premi, Klaim, dan Pertumbuhan Aset". Universitas Islam: Bandung. http://repository.unisba.ac.id...0 6bab2_Muhammad\%20Ikhsan 1001021002.pdf (diakses 7 Juni 2016).

Kartini, Indira. 2016. Operasionalisasi Badan Penyelenggara Jaminan Kesehatan (BPJS). Tesis Magister; Program Pascasarjana UIN Sunan Kalijaga: Yogyakarta. http://digilib.uinsuka.ac.id/21845/1/142031000" _BAB-I_IV-atau-V_DAFTAR- 
| Diktum: Jurnal Syari'ah dan Hukum, Volume 16, Nomor 2 Desember 2018 : 307 - 338

PUSTAKA.pdf. (diakses 12 Februari 2017).

Kementrian Kesehatan RI. "Buku Pegangan Sosialisasi Jaminan Kesehatan Nasional (JKN) dalam sistem Jaminan Sosial". http://www.depkes.go.id/resour ces/.../jkn/buku-pegangansosialisasi-jkn.pdf (diakses 1 April 2016).

Majlis Taqarrub Ila Allah. Hukum Riba dan Bunga Bank. https://alqandaly.wordpress.co $\mathrm{m} / 2013 / 11 / 04 /$ hukum-riba-danbunga-bank/ home (diakses 8 April 2016).

Majelis Ulama Indonesia. 2015. "Hasil Ijtima' Ulama Komisi Fatwa se-Indonesia V Tahun 2015. http:// MU-Hasil-Ijtima-UlamaV-tahun-2015.pdf (diakses 7 Maret 2016).

Manan, H Abdul. 2012. Hukum Ekonomi Syariah: Dalam Perspektif Kewenangan Peradilan Agama. Jakarta: Kencana Prenadamedia Group.

Ma'rufah, Nur. 2009. Sistem Pengelolaan Dana Yayasan Panti Asuhan Taman Thoyyibah Sedati Gede Siduarjo. Skripsi Sarjana: Fakultas Dakwah UIN Sunan Ampel Surabaya: Surabaya. http://digilib.uinsby.ac.id77673 bab\%202.pdf (7 Juni 2016).

Moleong, Lexy J. 2010. Metodologi Penelitian Kualitatif. Bandung: PT Remaja Rosdakarya.

Muhamad. 2008. Metodologi Penelitian Ekonomi Islam
Pendekatan Kuantitatif Jakarta: Raja Grafindo Persada.

Peraturan Menteri Kesehatan Republik Indonesia Nomor 52 Tahun 2016 Tentang Standar Tarif Pelayanan Kesehatan dalam Penyelenggaraan Program Jaminan Kesehatan.

Pusat Pengkajian Hukum Islam dan Masyarakat Madani. 2009. Kompilasi Hukum Ekonomi Syariah. Jakarta: Kencana.

Republik Indonesia. 2016. "Peraturan Presiden Republik Indonesia Nomor 19 Tahun 2016 Tentang Perubahan Kedua Atas Peraturan Presiden Nomor 12 Tahun 2013 Tentang Jaminan Kesehatan". http://PERPRES No. 19 Th 2016 ttg Jaminan Kesehatan.pdf (diakses 7 Juni 2016).

Rusdi, Muhammad Ali. "Maslahat sebagai Metode Ijtihad dan Tujuan Utama Hukum Islam." DIKTUM: Jurnal Syariah dan Hukum 15.2 (2017): 151-168.

Rokhaningsih. 2008. "Tinjauan Hukum Islam terhadap Akad Tabarru' di PT. Asuransi Takaful Keluarga Semarang”. Skripsi Sarjana; Fakultas Syariah IAIN Walisongo: Semarang. http://jtptiain-gdl-rokhanings4035-1-2103104.pdf (diakses 7 Maret 2016).

Situs Resmi BPJS Kesehatan. http://www.bpjskesehatan.go.id/. (diakses 30 Desember 2016). 
| Diktum: Jurnal Syari'ah dan Hukum, Volume 16, Nomor 2 Desember 2018 : 307 - 338

Situs Resmi Kota Parepare, http://www.pareparekota.go.id/. (diakses 29 Desember 2016).

Suhendi, Hendi. 2002. Fiqh Muamalah. Jakarta: Raja Grafindo.

Sula, Muhammad Syakir. 2004. Asuransi Syariah (life and general): Konsep dan Sistem Operasional. Jakarta: Gema Insani Press.

Syafei, Rachmat. 2001. Fiqh Muamalah. Bandung: Pustaka Setia.

Tim Pustaka Yustisia. 2014. Panduan Resmi Memperoleh Jaminan Kesehatan dari BPJS. Visi Media. https://books.google.com/books (diakses 18 Januari 2017).

Triyanta, Agus. 2012. Hukum Ekonomi Islam dari Politik Hukum Ekonomi Islam sampai Pranata Ekonomi Syariah. Yogyakarta: FH UII Press.

Zainuddin, A dan Muhammad Jamhari. 1999. Al-Islam 2 Muamalah dan Akhlak. Bandung: Pustaka Setia.

Zulkahfi. 2014. Jaminan Kesehatan Nasional (JKN) Perfektif Hukum Islam. Skripsi Sarjana; Fakultas Syari'ah dan Hukum UIN Sunan Kalijaga: Yogyakarta. http://digilib.uinsuka.ac.id/.../2/10380002_babi_iv-atau-v_daftar-pustaka.pdf 
| Diktum: Jurnal Syari'ah dan Hukum, Volume 16, Nomor 2 Desember 2018 : 307 - 338

\section{Catatan Akhir}

1 Yusuf Qardhawi, Peran Nilai dan Moral dalam Perekonomian Islam, Rabbani Press, Jakarta (1995)

${ }^{2}$ Badan Pusat Statistik, Makassar dalam Angka 2010, 2010.

${ }^{3}$ Al-Haritsi, Jaribah bin Ahmad, Fikih

Ekonomi Umar bin al-Khattab (Jakarta: Khalifah 2006), h.58.

${ }^{4}$ Hawkins, D, Consumer Behavior:

Building Marketing Strategy, (7th Edition)(New York: McGraw-Hill, 1998), h.42.

${ }^{5}$ Engel, J.F, Perilaku Konsumen,
(Edisi Keenam)

Budijanto(Jakarta: Binarupa Aksara, 1995), h. 23 .

${ }^{6}$ Mowen, John, C., dan Minor, Perilaku Konsumen Jilid 1, Edisi Kelima (terjemahan)(Jakarta: Erlangga, 2002), h.21.

${ }^{7}$ Ibid h.71.

${ }^{8}$ Schiffman, L.G dan Kanuk, Lesley L, Panduan Riset Perilaku Konsumen(Jakarta: PT. Gramedia Pustaka Utama, 2007), h.15.

${ }^{9}$ Engel, J.F., R.D, Blackwell., and P.W, Miniard, Perilaku Konsumen (Jakarta: Binarupa Aksara, 1994), h.19.

${ }^{10}$ Peter, Paul. J and Olson, C. Jerry, Perilaku Konsumen dan Strategi Pemasaran. Cetakan Keempat Jilid-1 (Jakarta: Erlangga, 1999), h.10.

${ }^{11}$ Salomon, R. Michael dan Stuart, W. Elnora, Marketing Real People, Real Choices, International Edition(New Jersey: Prentice Hall, 2003), h.47.

${ }^{12}$ Mashlahah secara bahasa berarti kebergunaan (utility) atau kesejahteraan (welfare), yang oleh Abu Hamid Al Ghazali $(505 \mathrm{H} / 1111 \mathrm{M})$ dan Abu Ishaq Al Shatibi (790 H/1388 M) masalih (plural of Mashlahah) dibagi menjadi tiga kategori; esensial (essential/daruriyah), pelengkap (complementary/hajiyah) dan keinginan (desirable/tahsiniyah). Dan tugas negaralah yang memastikan kemashlahatan kategori pertama dari masyarakat itu terpenuhi dengan baik. Lihat Muhammad Akram Khan, 'The Roleof Government in the Economy," The
American Journalof Islamic Social Sciences, Vol. 14, No. 2,1997, p. 157.

${ }^{13}$ Yusuf Qardhawi, Peran Nilai dan Moral dalam Perekonomian Islam, Rabbani Press, Jakarta (1995).

${ }^{14}$ Lihat Sadono Sukirno, Pengantar Teori Mikroekonomi, Rajawali Press Jakarta, 2002.

${ }^{15}$ Hasan Al Banna, Risalah Pergerakan Ikhwanul Muslimin, Intermedia, Jakarta 1997. hlm. 387-409.

${ }^{16}$ Chapra, Muhammad Umer, Islam and the Economic Challenge, The Islamic Foundation and the International Institute of Islamic Thought, edition: 1995, pp.29

${ }^{17}$ Mannan, M.A. The Making of Islamic Economics Society, Islamic Dimensions in Economics Analysis, pp.24, First Edition: 1984, International Association of Islamic Banks, Cairo, Egypt.

${ }^{18} \mathrm{Kahf}$, Monzer. A Contribution to the Theory of Consumer Behavior in an Islamic Society, in K. Ahmad ed., Studies in Islamic Economics, pp. 19-36. Jeddah, Saudi Arabia: International Center for Research \& Islamic Economics, King Abdul-Aziz University, 1980.

${ }^{19}$ Kahf, Monzer. The Demand Side or Consumer Behavior, Principles of Islamic Economics, Chapter four, Kuala Lampur, Malaysia: International Islamic University of Malaysia (IIUM), 1996.

${ }^{20}$ Hasan, Zubair, 1985. Fahim Khan; Macro Consumption Function in an Islamic Framework -Comments, Journal of Research in Islamic Economics, Jeddah Vol. 2, No. 2, Winter,pp.79-81.

${ }^{21}$ Hasan,Zubair, 2005. Treatment of Consumption in Islamic Economics: An Appraisal,Journal of Islamic Economics, King Abdul Aziz University, Vol. 18, No. 2, pp. 2946 (2005 A.D/1426 A.H)

${ }^{22}$ Khan, Fahim, Macro Consumption Function in an Islamic Framework, Journal of Research in Islamic Economics., Vol. 1, No. 2, pp. 3-25, 1984 or (Essay in Islamic economics. Islamic foundation, U.K, 1995,

${ }^{23}$ Al-Zarqa, Muhammad Anas. A partial relationship in a Muslim utility function, in Readings in Microeconomics in 
| Diktum: Jurnal Syari'ah dan Hukum, Volume 16, Nomor 2 Desember 2018 : 307 - 338

Islamic Perspective edited by sayyid tahir, aidit ghazali, syed Omar and syedazil, chapter eight,pp.105-112,first edition,1992,Longman, Malaysia.

${ }^{24}$ Siddiqi, M.N. 2001. Economics: An Islamic Approach, PP.71-81, Institute of Policy Studies, 2001, original from the University of Michigan.

${ }^{25}$ Haider Naqvi, Syed Nawaz. 1997. The Dimensions of AN Islamic Economic Model, Journal: Islamic Economic Studies, Vol. 4, No. 2, May 1997

${ }^{26}$ Khan, Fahim. An Alternative Approach to Analysis of Consumer Behaviour:Need for Distinctive "Islamic" Theory, Journal of Islamic Business and Management Vol.3 No.2, 2013

${ }^{27}$ Mannan. Teori dan Praktek Ekonomi Islam, (Yogyakarta: Dana Bhakti Wakaf, 1995). h. 29

${ }^{28}$ R.7, Wawancara dengan Responden yang tidak ingin dituliskan namanya, 2 Februari 2017.

${ }^{29}$ R.27, Wawancara dengan Responden yang tidak ingin dituliskan namanya, 2 Februari 2017.

${ }^{30}$ R.110, Wawancara dengan Responden yang tidak ingin dituliskan namanya, 5 Februari 2017.

${ }^{31}$ R.92, Wawancara dengan Responden yang tidak ingin dituliskan namanya, 8 Februari 2017.

${ }^{32}$ R.57, Wawancara dengan Responden yang tidak ingin dituliskan namanya, 8 Februari 2017.

${ }^{33}$ Muhammad Hadi Al-Kharsani, Al'amal fi Al-Islam Wa Dauruhu fi AlTanmiyati Al- Iqtishadiyyah, (Beirut: Dar AlHadi, t.th), cet. ke-1, h. 37-38.

${ }^{34}$ Taqiyuddin an-Nabhani, Nizhamu al-Iqtishadi fi al-Islam, Diterjemahkan oleh Hafizh Abdurrahman, dengan judul "SistemEkonomiIslam",(Jakarta: Hizbuttahri Indonesia Press, 2010), h.21.

35R.71, Wawancara dengan
Responden yang tidak ingin dituliskan namanya, 10 Februari 2017.

${ }^{36} \mathrm{Ibid}$, h.78

${ }^{37}$ Perbedaan penimbunan atau penumpukan harta dan tabungan (saving), Penimbunan berarti mengumpulkan uang satu dengan uang yang lain tanpa ada kebutuhan, dimana penimbunan tersebut akan menarik uang dari pasar. Mengumpulkan harta semacam ini termasuk kategori tindakan yang dicela. Saving adalah menyimpan uang karena adanya kebutuhan, semisal mengumpulkan uang untuk membangun rumah, ataupun untuk keperluan yang lain. Bentuk pengumpulan uang semacam ini tidak akan mempengaruhi pasar, dan tidak akan mempengaruhi aktivitas perekonomian, sebab tindakan tersebut bukan merupakan tindakan menarik uang, namun hanya mengumpulkan uang untuk dibelanjakan, dimana uang yang dikumpulkan tersebut akan beredar kembali ketika dibelanjakan pada objek pembelanjaannya.

${ }^{38}$ R.13, Wawancara dengan Responden yang tidak ingin dituliskan namanya, 11 Februari 2017.

${ }^{39}$ R.71, Wawancara dengan Responden yang tidak ingin dituliskan namanya, 11 Februari 2017.

${ }^{40}$ P3EI UII, Ekonomi Islam, Jakarta: PT Raja Grafindo Persada,2014, h.129

${ }^{41}$ Hasil analisis NVivo

${ }^{42}$ Hasil kategorisasi NVivo, 2017

${ }^{43}$ Hasil kategorisasi NVivo, 2017

${ }^{44}$ Hasil kategorisasi NVivo, 2017

${ }^{45}$ Hasil kategorisasi NVivo, 2017

${ }^{46}$ Hasil kategorisasi NVivo, 2017

${ }^{47}$ Hasil kategorisasi NVivo, 2017

${ }^{48}$ Hasil kategorisasi NVivo, 2017

${ }^{49}$ Hasil kategorisasi NVivo, 2017

${ }^{50}$ Hasil kategorisasi NVivo, 2017

${ }^{51}$ Hasil kategorisasi NVivo, 2017 